號十六百二第

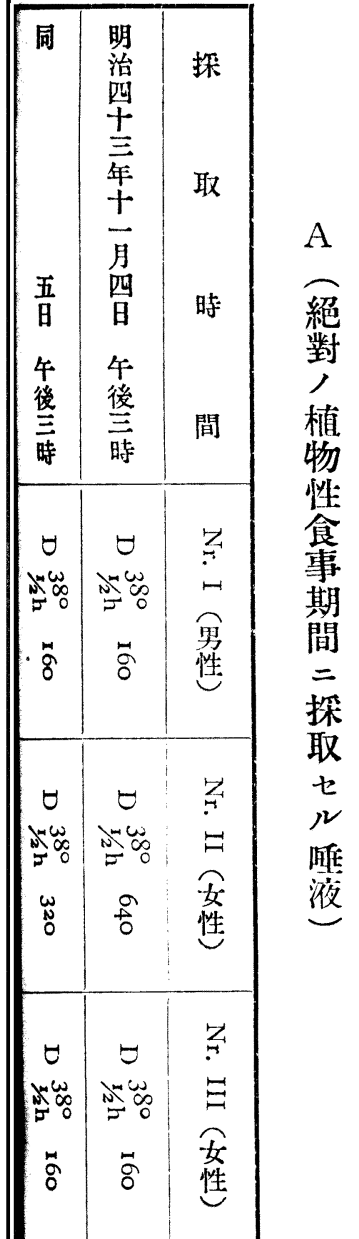

万但 植次

モ $シ$ 物 二

可唓 性 余

ナ留 食 心

ル探畣食

）取，品第第

信, ミ, 算

又時 7 性

卜間以質㗖唾

雖 = テ 卜 液 液

第余關 江咺,

八 シ 第 液 澱 澱

便 テ 消 粉 粉

二宜 $、$ 日化消消

上覞 以力化化

常二降年力力

人

類

咞在

波

表二前七, 心小

午二日關其食

後述留係分嵒

严 7 泌,

時夕通知量性

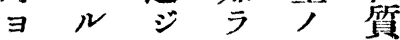

リガテン多ト

四如試卜少關

時 方驗 欲二係

, 余 7 㣹 7

間, 反荮泣有

化

於試覆再强

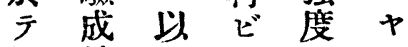

探 績 亏 前二

取 二 得 記 戀

せ據夕, 化

リル

バ成名り

全績 二

早示先

力

通 ス 與

浮

テ $ト$

何庄

表 全

就

濊

, , 十

時 如 $\mathrm{日}$

二 シ 間

於絶

广

ナ

$\mid \begin{array}{ll}\mathfrak{n} & \text { テ } \\ \text { ト } & \\ \text { ル } & \text { 承 }\end{array}$

平

田

吾 
二 第

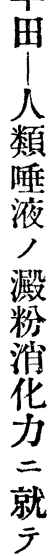

乃但 少 此 至今り試 試 其少西試 シ 驗 驗 大 $才$ 時 驗 $7=7$ 多弦, 以着終 數三間期 三手 少 八記二日余七夕

B

百不唾 自りル

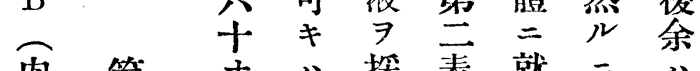
肉第ナ八探表就三八

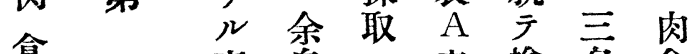
食事自䒾檢名食 就時二他體以, 查共時 テ 二 三唾檢クル多探 探表名液香七儿量取 取 三 消 $习$ 日省七 七

ル

挐

隻 相化施間、肉次 相吕行食睡 致”七シセ液 七毁り試り嫌消 $y=$ 驗总化 㯪前箭方 今 前陚, 檢白羷 查以, 度 七降 第 $\exists$ 旦

掌查

笋

臭改

兵 8

学

乃洋

至食

百

四

白

$+$

, 亦

間便

）宜

是卓

的

就

中

曶試

日 驗

以

降

到 $r$

底 欲

持

續 前

三 記

天 同

檢 栐

丝

$=$

亦

季咅

施

行 研

又究

少林

ב 料

$r \quad r$

能 シ

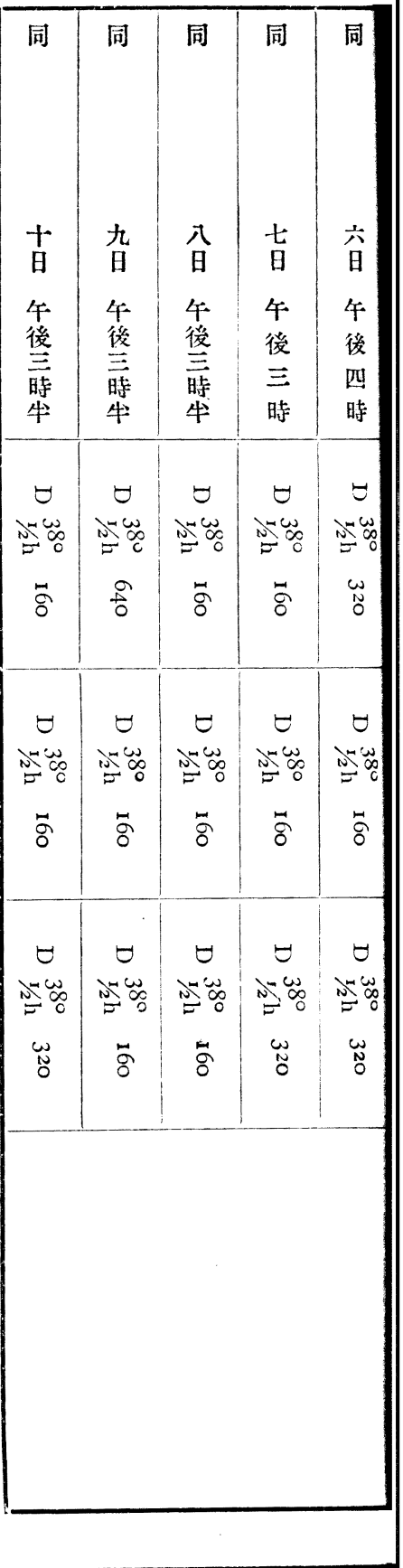


七嫦倘數名令 然本, 7 前 事广之場通記 $\exists$ リ 二 合 認 一次二テ表

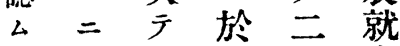
$儿$ 於 $\mathrm{B}$ 广

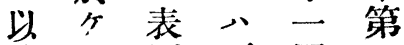
外兄則面国三 二哑于空, 表 於液肉十試 $\mathrm{A}$ テノ食度盎表 敢消封二中則

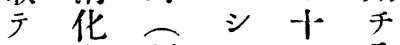
其力絶于四全 消 $\rightarrow$ 對 其间 干 化通, 少, 日 力覽 肉數面間 二食, 兵 强ルニ場十通 弱 $=\Gamma$ 合度 縱 ス 分 於五紹 事材卜元匟對 實 料踓, 八二 $\exists=$ 絕 三 三植 發 於 對 三百物 見于 百主 入甚植三十 ル多物十度探 二少食乃取 卜數三至二七 能ナ比突可ル 八リ 万百八場 ズ卜レ四六合 之踓 バ十百二 贸實度四於 先 $==二 十 r$ 輩於大薘度 ノテナス 則偊 試モルル千液 驗亦差動荮, 二普 $\Rightarrow$ 搖 二 澱 比通有 $\Rightarrow$ 於 粉 僌, ス 示 天 消 ス昇ル不化 降 二者亦力 $=\Rightarrow r$ 卜 食ナ八氺多三

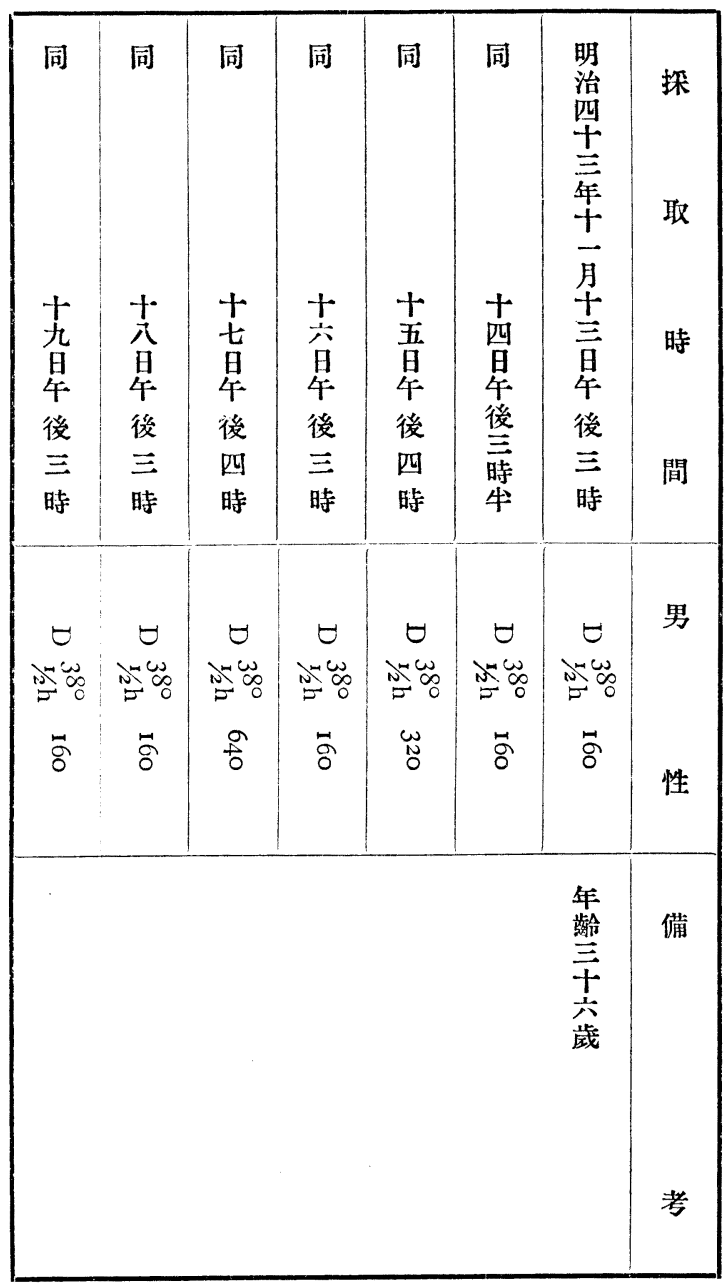




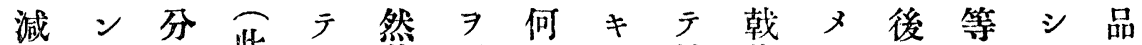
人少 泌䠌試某證種 $尹$ 是作夕二,

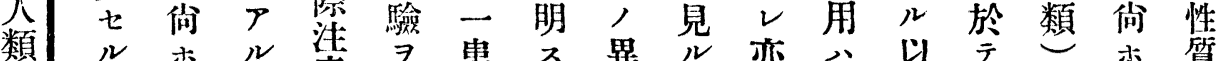

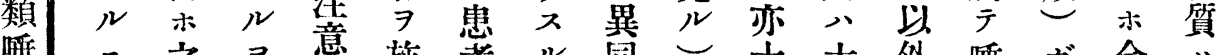

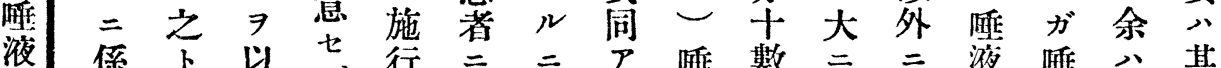
八 係上以 ザ行

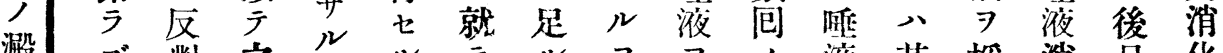

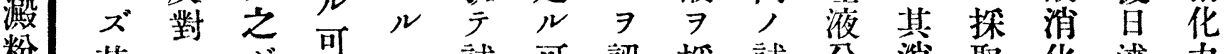
粉 其 $=カ ゙$ 可二試可認探試分消取化述力

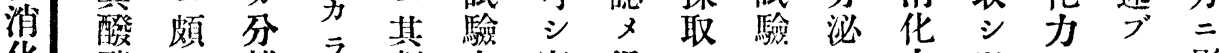

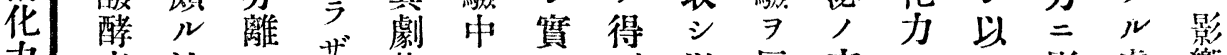

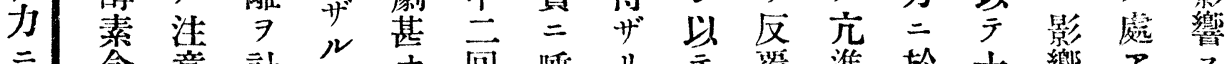

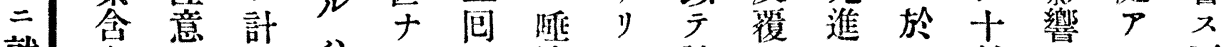

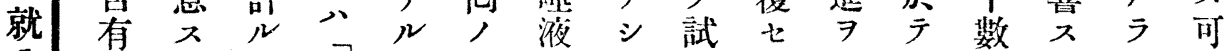
テ

量可

$=\neq ア$ 泌

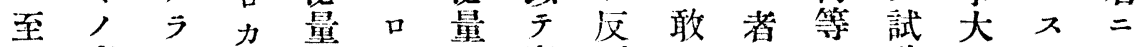
り事ザルタカ占實覆テタ, 驗ナルケ

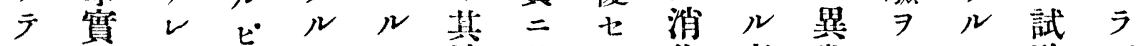

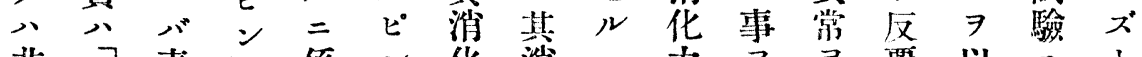

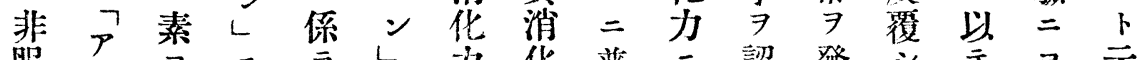
服 $P{ }_{\exists}$ 二 用口り因 ズ法上方通影 見夕食りフ

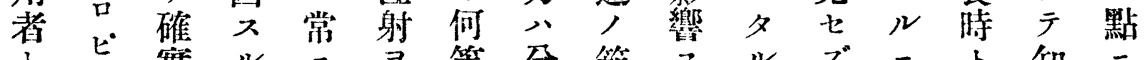

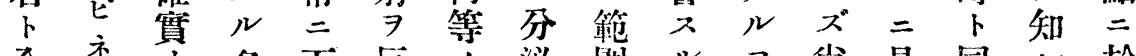

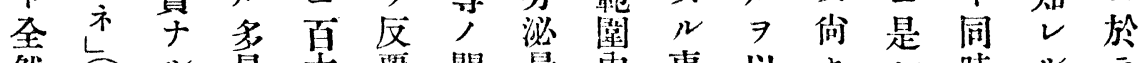
然亘ル量六復關量内事以和レ時ルテ

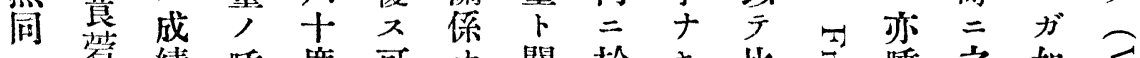

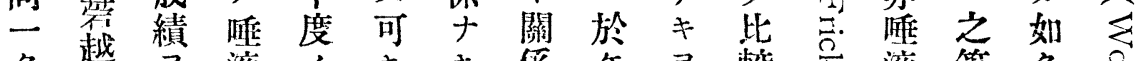
夕越 $\exists$ 液 $\neq \neq \neq$ 係 ル戴擧分消機事ナル以的只分刺諸吅

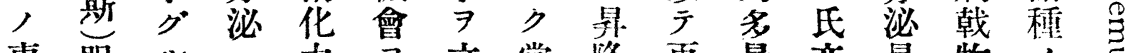
事服 $ン$ 力 $\exists$ 立常降再量亦量物了主 二用 $=$ 當 $\exists$ 得證二, ビ, 既, , 刺

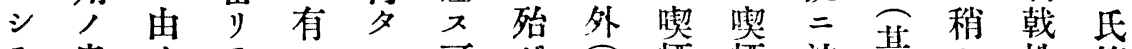

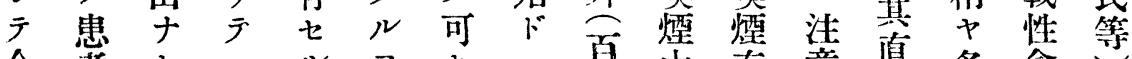
今著 $\neq$ 八 荮, 八之者以唯定六二後七㣪量品全

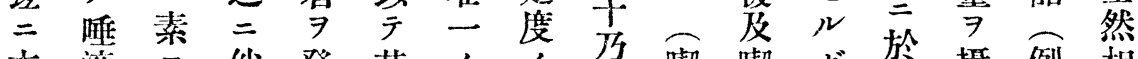

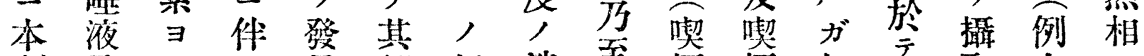
七劑分り>見都好消意煙煙如 方取之:

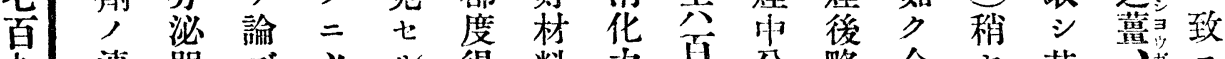

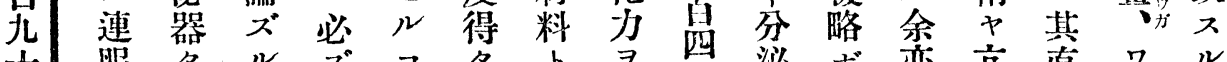

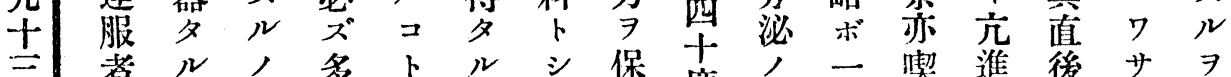
者ル人多トルシ保度, 一䒜進後サ

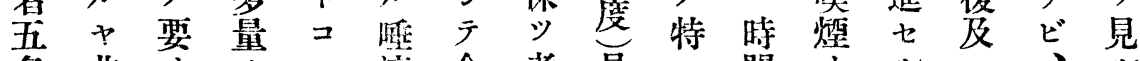

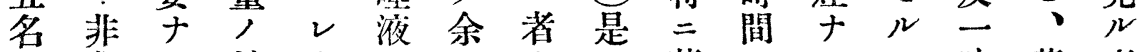
二常力粘ナ

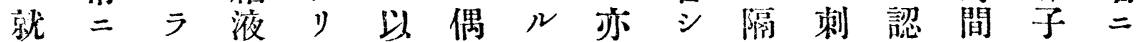


號十六百二第

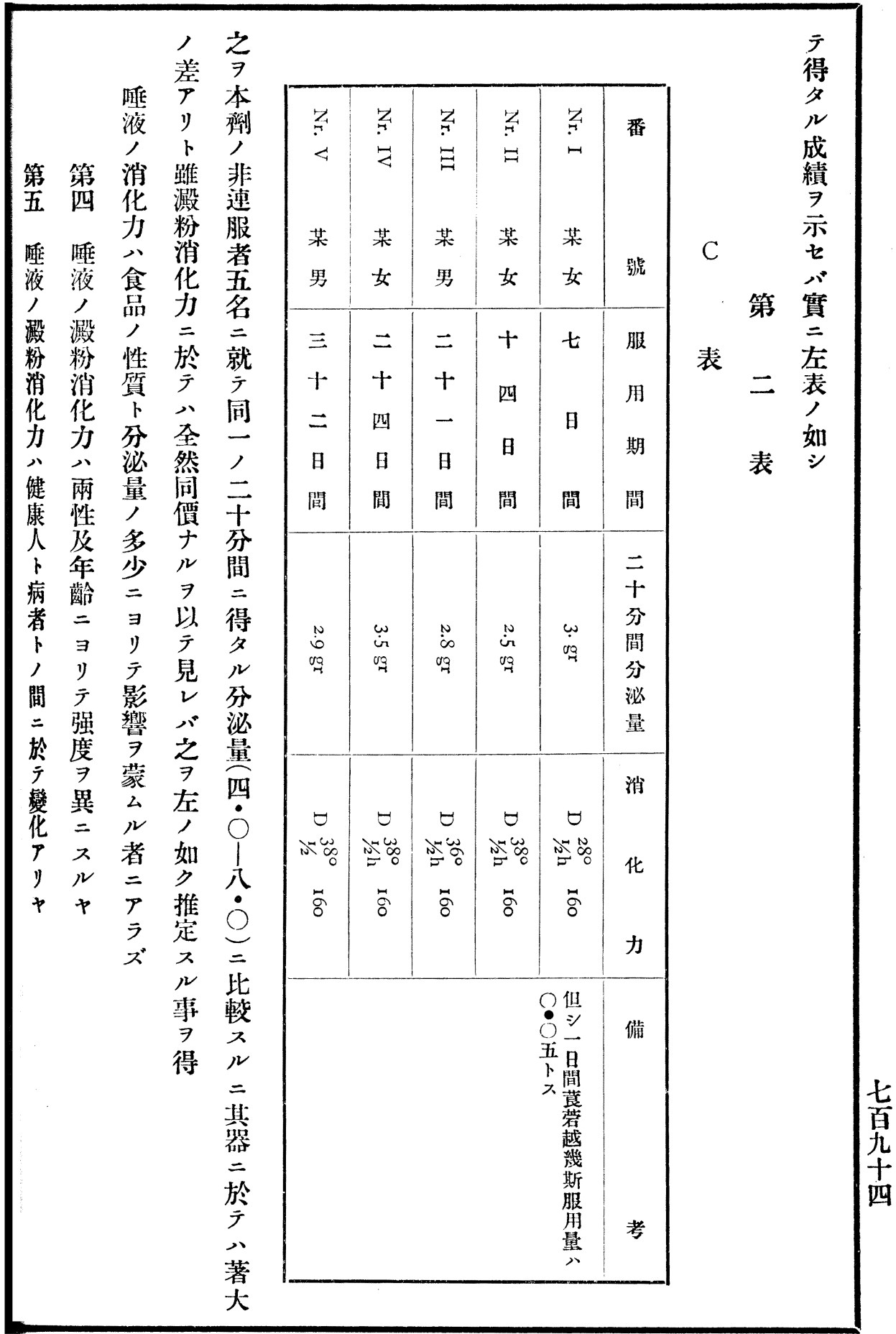


$+$

兵百

二 第

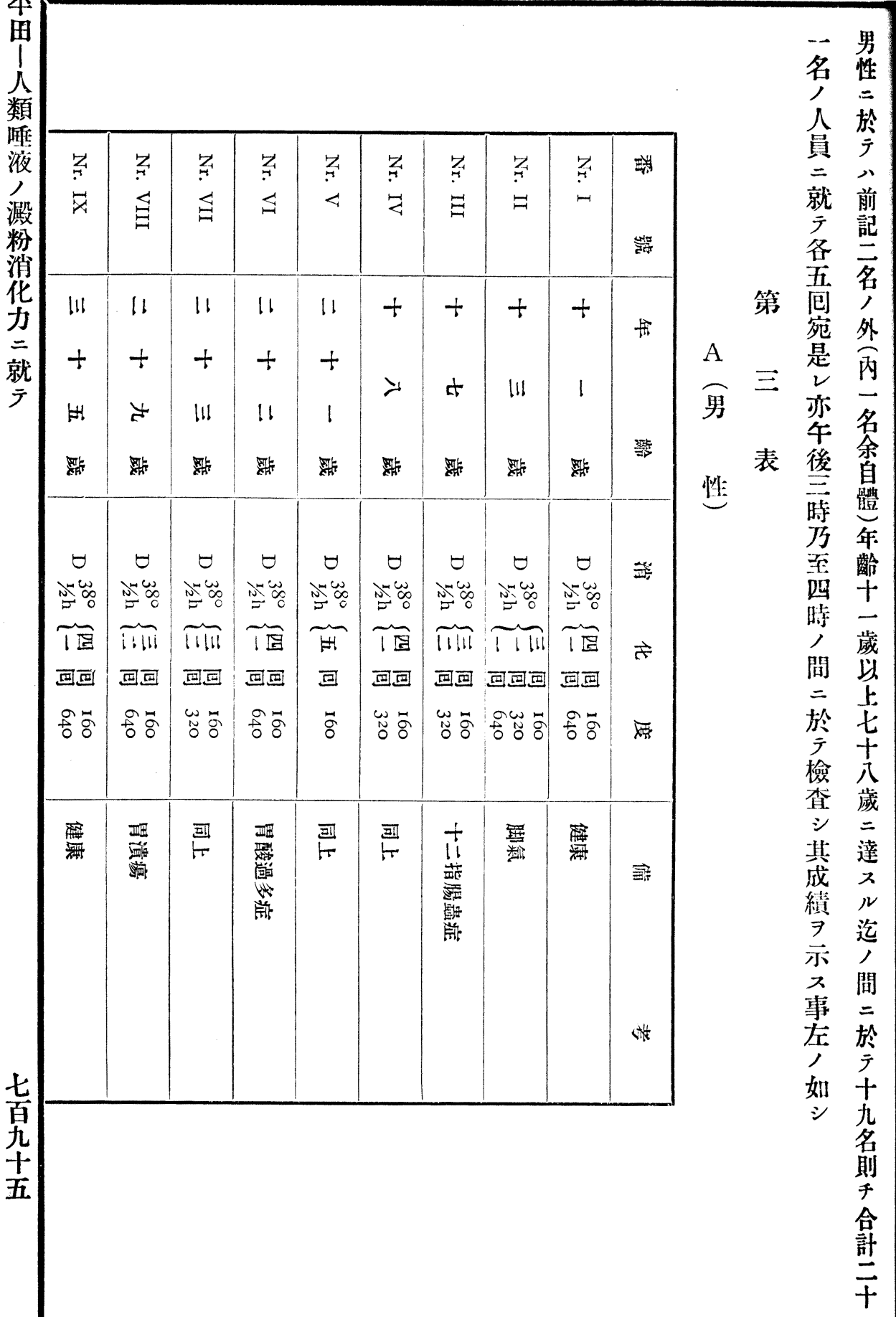


號十六百 三第

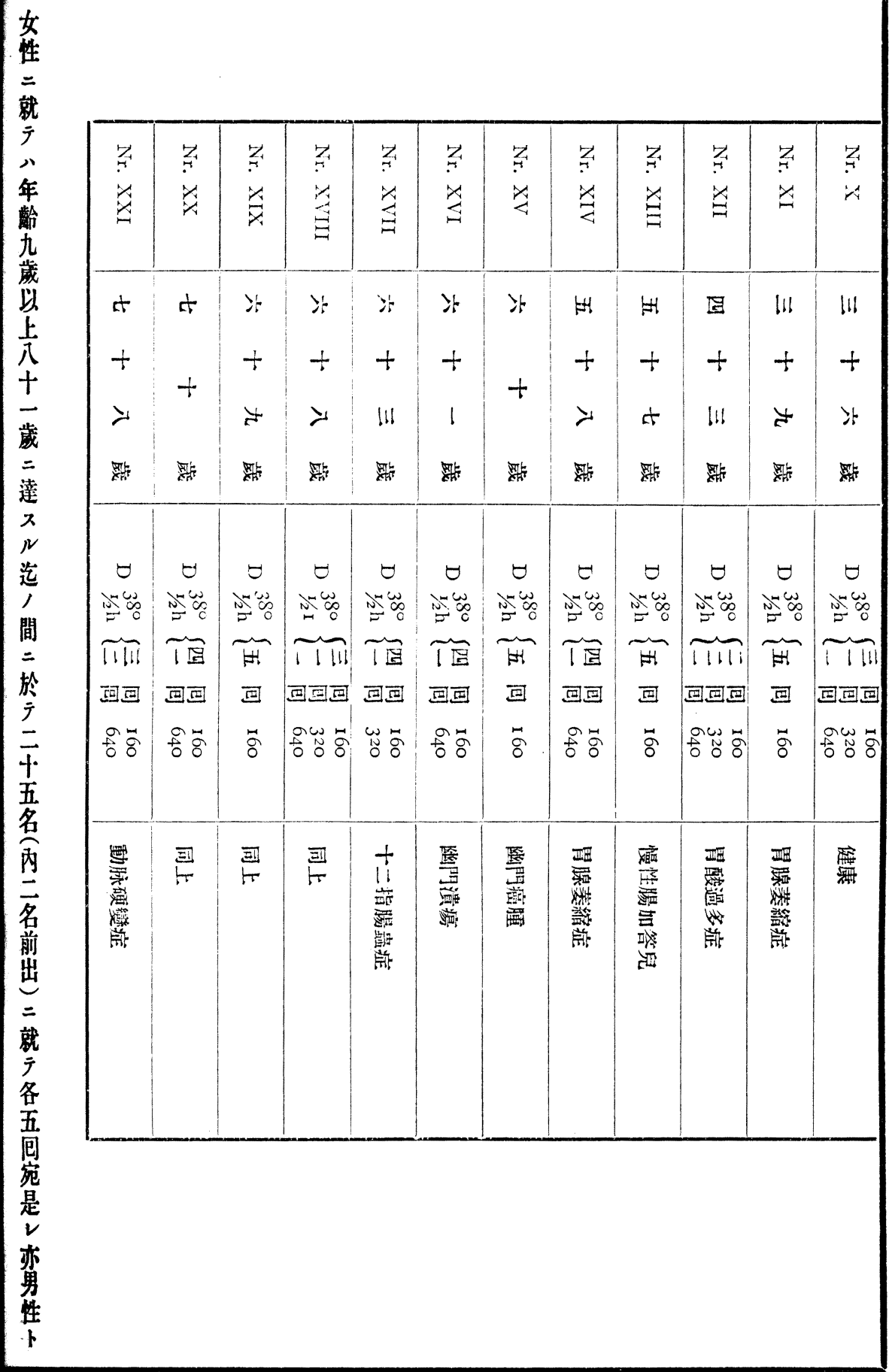


21 號 1 六 百二第

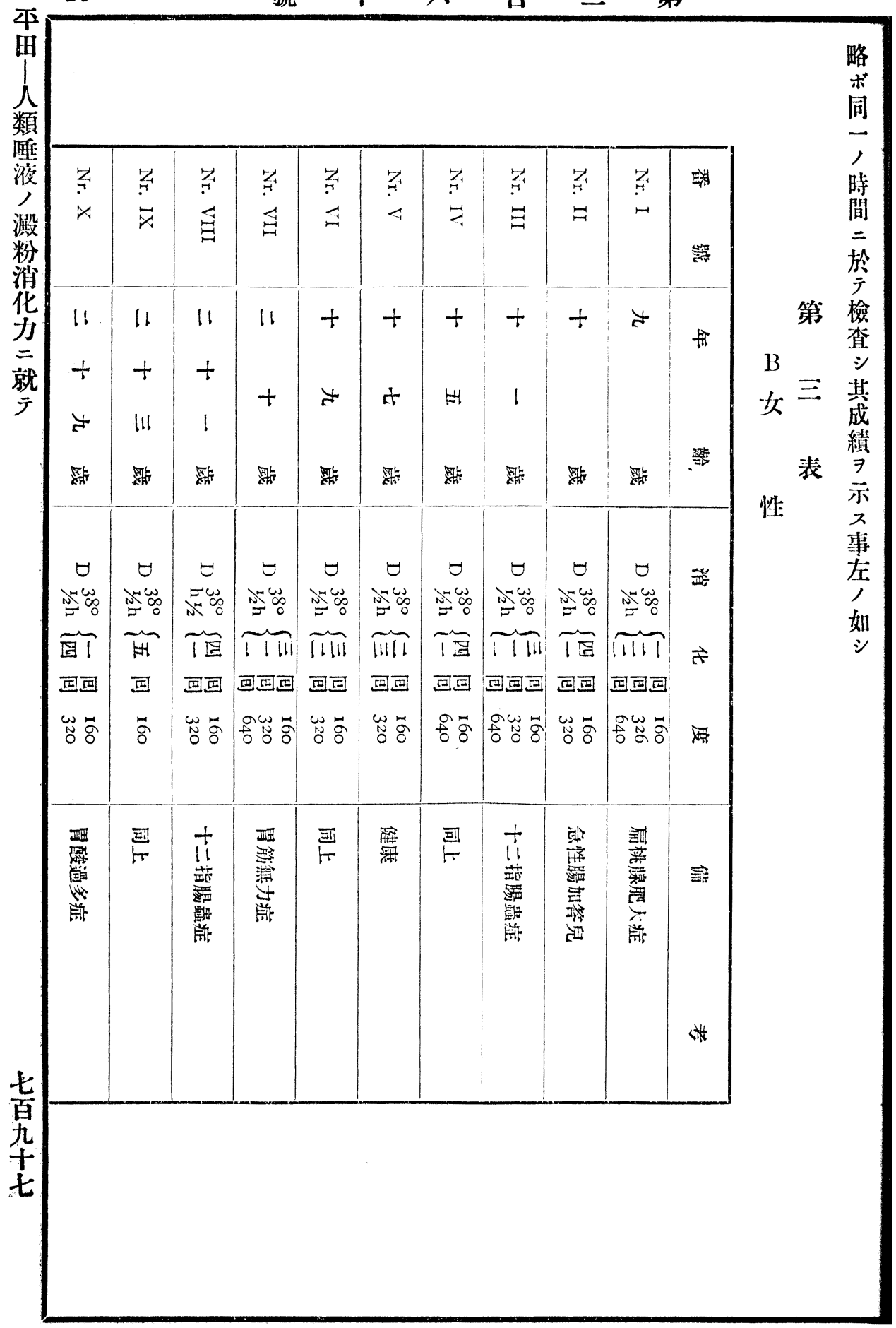


號十六百二第

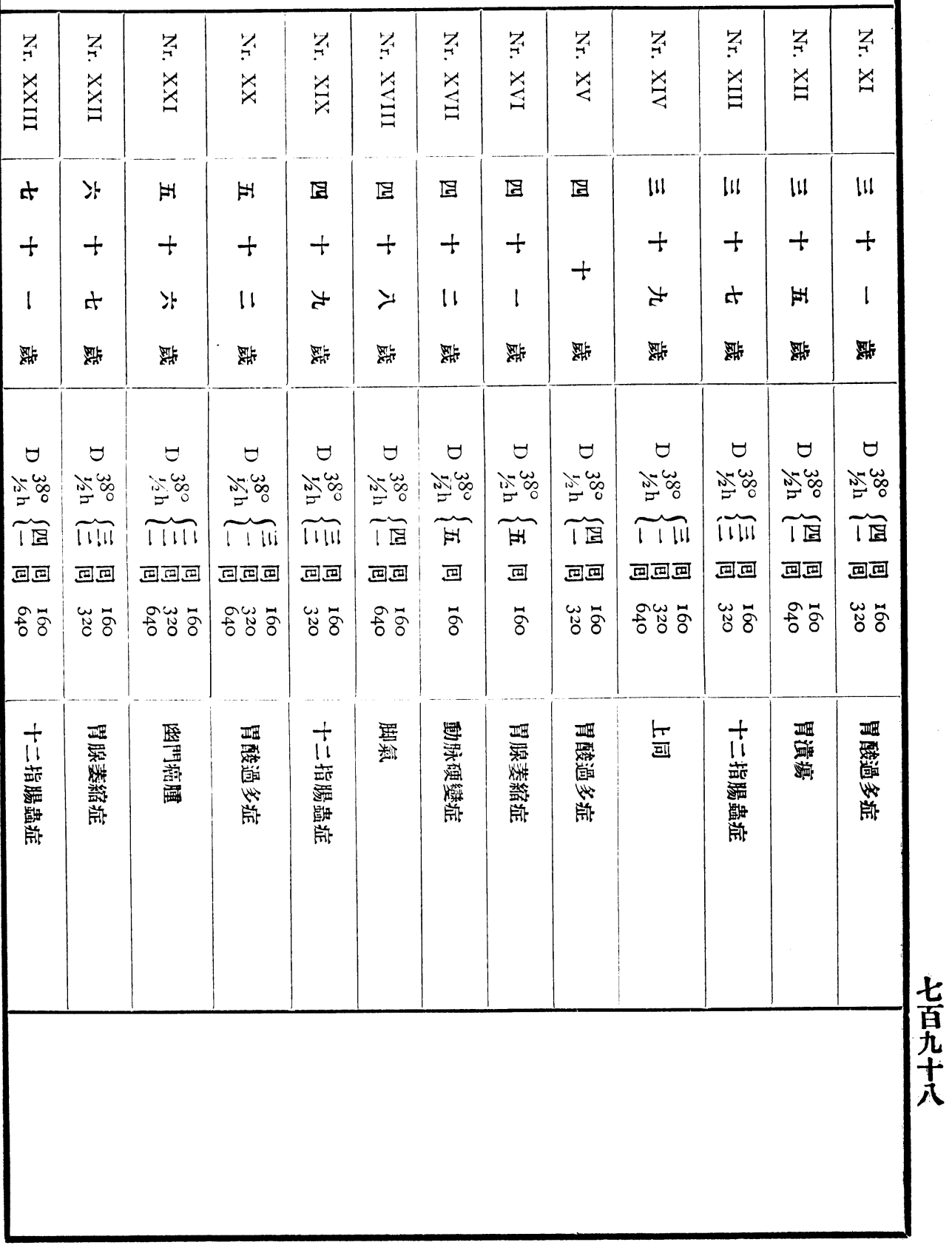


23 號十六百二第

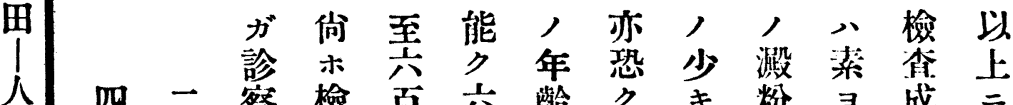

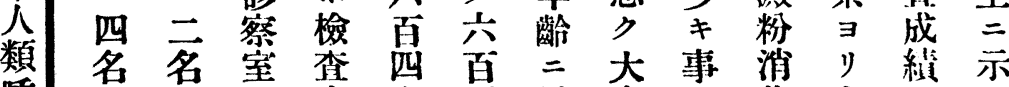
唓名室查四百二大事消り維示

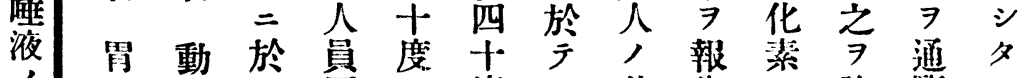

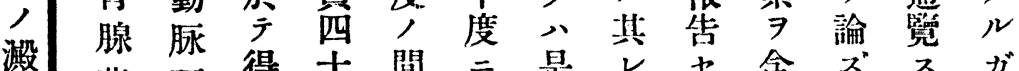
巷 硬得十間 $=$ 是 $v$ 含 $x^{\prime}$ ス

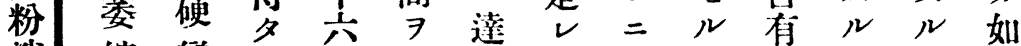

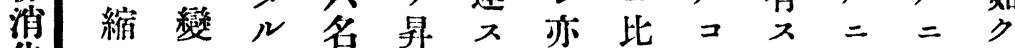

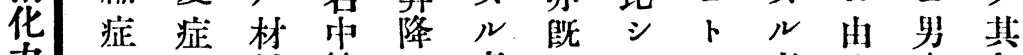
力 料 健 $又$ 事二テ厂者ナ㚣午 二 則康 $ル ア$ 述差り, ク兩齡 就者者ル令異之如只性,

テ 四一患占占 7 タ $\gamma$ 等 名名著認断以儿炒倘芯於小 二厶定示處可事水焉方ナ 胃扁 シ 可米實人 桃 $\neq$ 得 $=$ 成 7 采及文 潰腺之者可各綪 想り喕吹差九

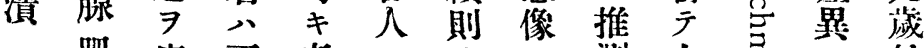
肥病兩者二千不測人寻学最

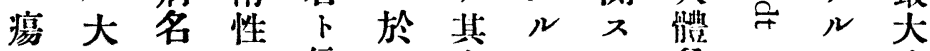
$=\exists$ 信 $\overline{\text { 大 }}=$ 各,

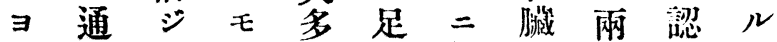

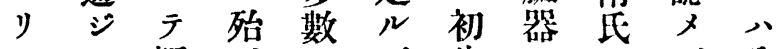

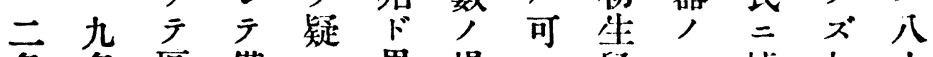

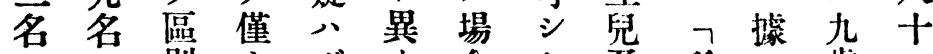

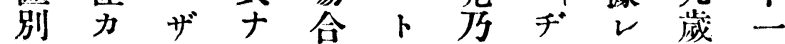
幽盐 ス 阴酸 ル㫐者事於少哺 洞二名ナナテナ孚タ類, 達 癌過左二リク心ク兒了初幼七 多人吾页卜三だ生兒ル

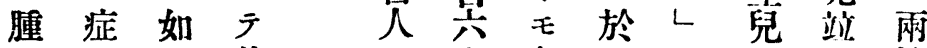
其人十九少， 他偊度葴 ル生ア分

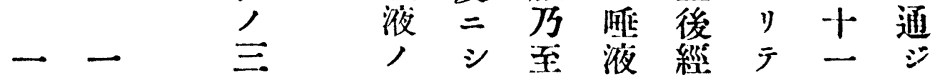

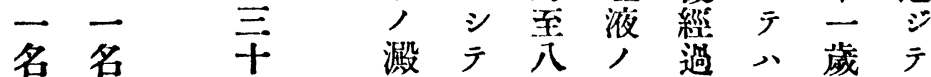

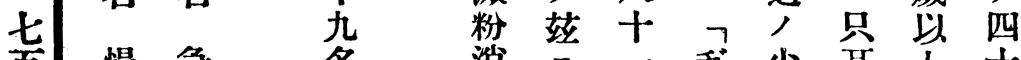
百慢急名涫三店少年十 兄性性化於葴ア手下, 宍 十腸晹於吕云前

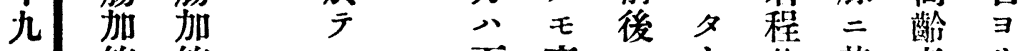

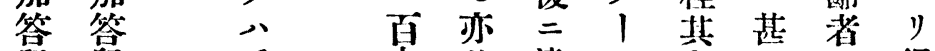

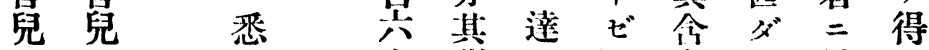
古强不有少於夕 余方度量量显亏心

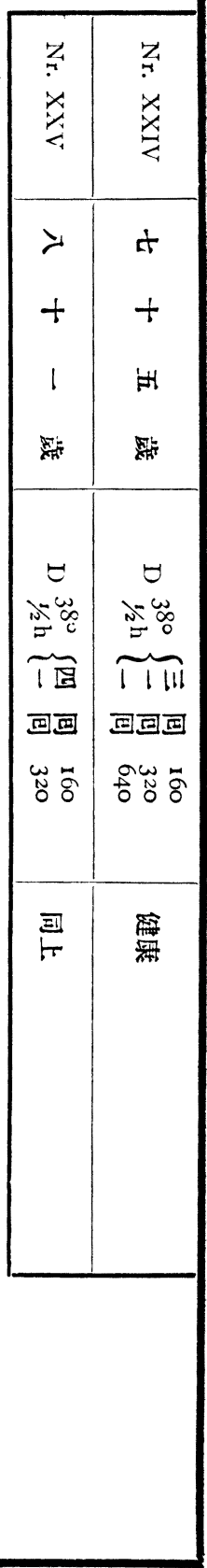


號十六百二第

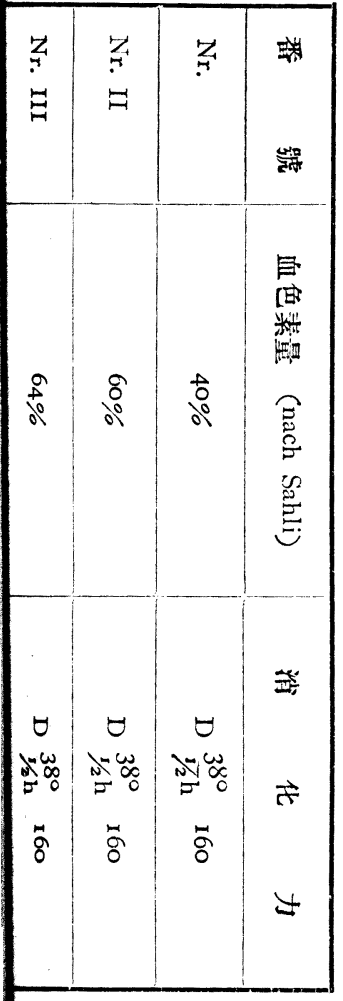

係 ル可二

二份》於

ラ 由

就水 其 天

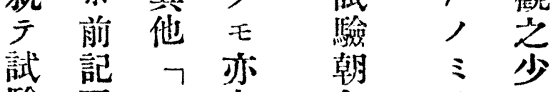

驗望モ之食た劣

平手占

後

ラト三脚

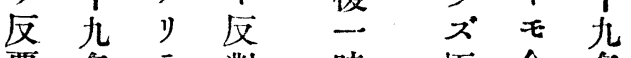

覆名亏對 時極余名

少 $1=$ 間 端 ガ

第其病 $卜$ 胃留 检

成者 L. 液液少

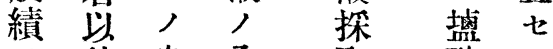

四 当外良全取酸出 示外否然分場

見亦䘖遊消泌合

表事上其芝離化,

左多沙七畦良光於

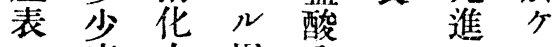

，高力笛分它皮

如度二腺十前

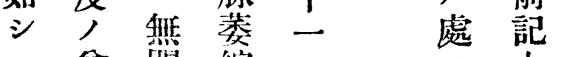

貧 關 縮

,

血 係 啮

酸 種

呈 如

過 類

七事總粘多,

$\mu$ 例 = 酸症 病

土命 $\urcorner$ 度液症

名胃少卆多丙言

, 酸モ九量名り

患缺常皇名多

者方二

= 症闹

就 及 價

于 幽 7

其 門 保

血癌 ッ

色湟者

素二夕

量於 ル

占事

消 之 $\Rightarrow$

胃 八

液 唾

檢 液

查,

成 消

化 7 知

續 化

览

記 二

サ 差

黑

$=7$

力 見

求

ト $=$

人 足

關足尘

氣

畣 多

名

幽

門

潰

瘍

名

\pm
痻
淘
症

名

胃 百 
25 號十六百二第

烡其百 本

繼 他 兵 表

續 余十

期 八度 示

間 蔇 万

万 二 度 處

至述宍二

前 乞 百 $\exists$

後夕四少

二

於方度之

テ㠰,

反昇考

覆二降

檢干寻年

查五示 =

七多 万血

ル, 以色

二女外素

是性何量

$v=$ 等,

亦 就 特 多

何 兾 少

等 檢, 亦

, 查意㵂

關七㧴液

係

$\exists, N$ 化

認間事力

$x 、 \Rightarrow=$

得内認何

ザ 至 メ 等

リ名ザ，

シ $=ル 2$ 關

事於者係

$\Rightarrow$ 厂

聯時 入有

二恰不

附无次

八記 月

百

七經時 ニ

$r=P$

ス會方

七

ル

$\Rightarrow$ 广

以 常

\begin{tabular}{|c|c|c|c|c|c|c|c|c|c|}
\hline 总 & 总 & 总 & 2. & $\frac{2}{4}$ & 总 & Z & 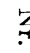 & 各 & Z \\
\hline$\stackrel{x}{\exists}$ & 坣 & $\ddot{a}$ & $x$ & $\bar{x}$ & 忍 & 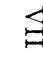 & $\$$ & 4 & \\
\hline
\end{tabular}

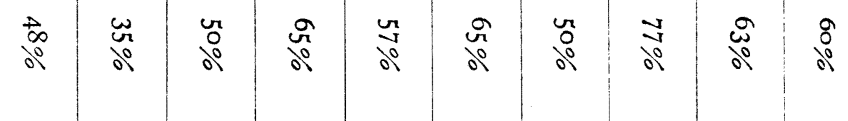

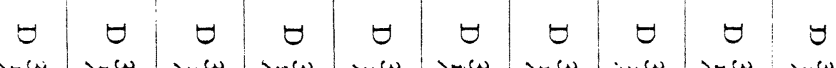

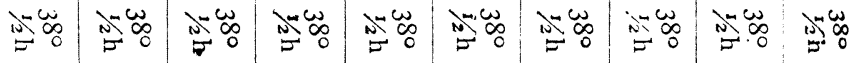

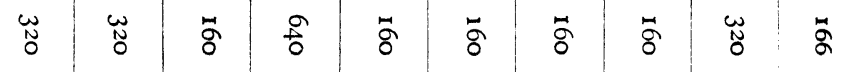


分卜終認度二者以 間 氏少, 企二上 $=$, = 於 試 臨

テ 䮑 ン

其 = デ

最 比 追

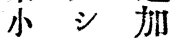

傮 賈 七

百 其 ン

二渻

十 化 欲

五力

度

於

最 会

大稍

價 $\uparrow$ 得

七强多

百度 ル

八ナ試

$+N$ 驗

度 事 成

ナ之績

Nナ

二 リ 之

比則

汗全

余同 然

, 氏 同

試 $=-$

驗據,

$=v$ 方

$\exists$ バ 則

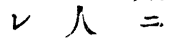

バ 類 據

三渪

干液

分, 檢

間 澱 查

二 粉 七

シ 消 ル

厂化 處

其为,

最八才

小實 ル

價 こ グ

既六

$=+1$
間 然 $P$ 余

$\exists$ 相

昇 一ザ試

降致少驗

入

ル卜卜績

者踓佾 $尹$

其办以

他一玄

$\bar{\gamma}=$ 方判

余於 = 斷

八 $\overline{7}$

之八午降

$\exists$ 先 前

以輩夕二

厂ノル單

寧諸 $卜=$

品年唾

生 績 後

理 5 ,

的更澱

範 二卜 粉

圍 符 = 消

二合於化

屬入方

ス $⿻$ 何

可 事等 決

キ 無,

ᄀ方

吾闹食

号总 $\Rightarrow$ 事

ン, 認 並

万偊要三

ע 液 得 食

グハズ 品

ᄂ 常卜,

卜 二云性

ナ百フ貿

入 共 點

事十 關

, 度於係

正方 $\bar{y}$

當至W 天

空氏增

百, 減

者四業 ス

古績光
ス 号学

コ交血十唺記

卜只獻色度液 所

$\Rightarrow$ 品 $=$ 素, 見

得等 徵 量 間 澱 二

入 入 亦 $\exists$ 粉依

單諸ル其昇消り

二士 二消降化左

記, 余化 万力,

啹人加

テ告 知二

參学》何

考 》得等

二卜 夕,

供雖ル意

セ笙義

シ $\exists$ 圍 $\exists$

ノリ内有

、 余 $=$ ス

余於

㸴者

究 心二

材今

料 日

卜 汽 ズ

八病

軌 的

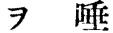

一 液

$=$,

ゼ ヂ

$\nu \gamma$

$\Rightarrow$ ㅈ

以. 夕

于 1

そゼ ズ

等 し

諸 二

先關

輩 シ

, テ

成

績

八推

兩定

性 二

、到

年 達

龄 七

哺り

乳

之

除

只

万丂

至

健

不

健

$=$

係

F

有

セ

常

=

皇

十

度

卜

相

對

照
上

政 
27 號十六百二第

田少關多澱抑本

木係量粉々表

人 - ナ量滥其,

類方 $\neq$ ᄀ化晶成

唩 $=コ$ 力

液 心ト $、$ 学

余 7 於火的

澱 余和ン

粉 試ツ ト 强以が

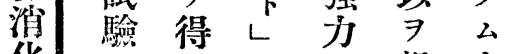

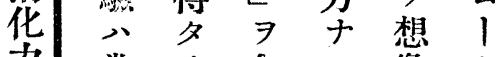

力常り含心候卜

二 二小有二ス就

就 一踓

テ 定是 $ア=$ 成

嘍 $レ$ 如 ラ 歐 續

ノ全 † ザ洲二

試ク 眼 ル比

驗 短 二 力 = 較

管 時 人? 比

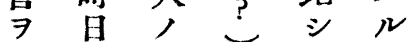

一) 和 何 テ=

定試少比其

淄驗所十輘最

度二ナ、的小

ノシルバ多價

水 $\ni$ 彼 量 二

浴之以少於

中 $\exists$ 草植 テ

二以十食物殆

挿亏リ動食占

入直縱物会音

先数余哑慣少

照 液七强

管 シ 前心少

内得揭肉處 7

八第食人有

温カ云動吾 ス

度 ラ 表物人ル

八等ザ

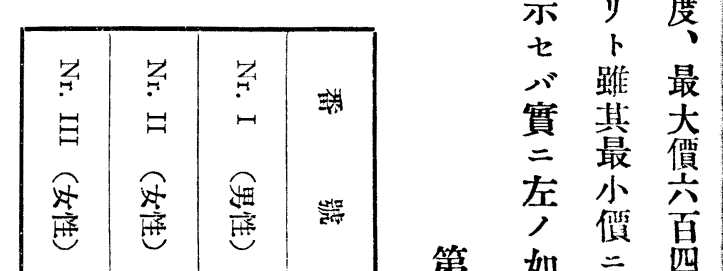

华弱直

古十

示 リ度

八゙踓最

第 如二四

$|+|$

於十

五.

示度

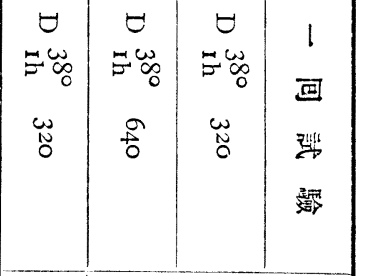

八 二

秒 シ

ヤ テ

表

高 實

度 二

多 加

ル 溫

7 時

知間

ルノ

二少

足心

ル十

可

余

今,

余成

ガ 績

W 7

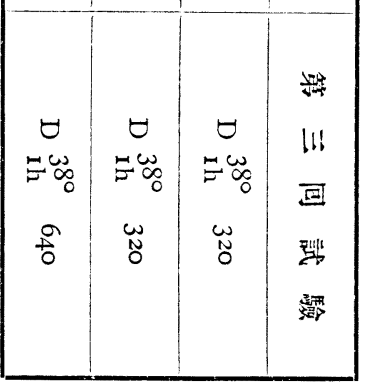

氏 氏

人

同成

時 績

間 二

貟比

十

尔

閪假

二命

於最

テ大

得 價

タ 二

儿於

消 テ 


\section{簤 算第第}

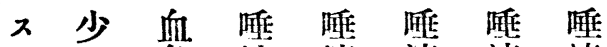

色液液 液 液 液

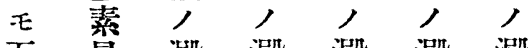

吾 量 澱 澱澱測澱

人 亦粉 粉 粉 粉 粉

日 消 消 漼 滥 消 消

本化 化 化 化 化 化

人少力加少力

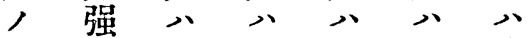

唩度少兩其食全 液二万性忽事目 澱何モ更泌卡

䊉等一年量食通

消ノ定龄ノ品涪

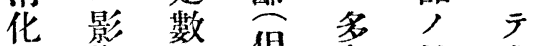

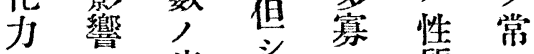

八 垁哺二質二

三及患笔應二略

十示鼠河示

分 於兒其等 一

間

二ト 八之崖關ノ

シ ナ健寻多係强

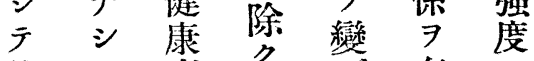

約者 年有

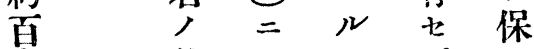

兵其 $\exists$ モ

十 レリリノ モ

度 テ =

万全 强 非

至然度 亏

亲间 $\exists$ ズ

百 一 異

四, =

十强七

度度 ズ

間有

7 ス

昇

降

ス

モ

>
キ 蓋ノ初

= シ $ト$ メ

非 余 ス テ

ラノ時

ザ試

間

$ル$ 驗 $\quad 7$

乎成算

記 績

シ ガ

テ オ

後 ル

結

日 ゲ

ノム

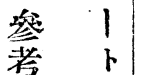

芦侖

E

x,

成

縝

$=$

㹈

シ

年

1).

相

堂

$\exists$

承

七

ル

f)

以

或

前

記

ᄀ

侄

件

,

何

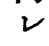

力

=

關

係
以

降

全

可

可

閏

水

溘

中

$=$

P

ラ

シ

$x$

及

ル

7

L.

テ

害

際

$=$

於

$\bar{Y}$

八

略

木

ए4

$+$

分

内

外

時

間

$\Rightarrow$

要

七

N

モ 
號

十 六 百

$=$

第

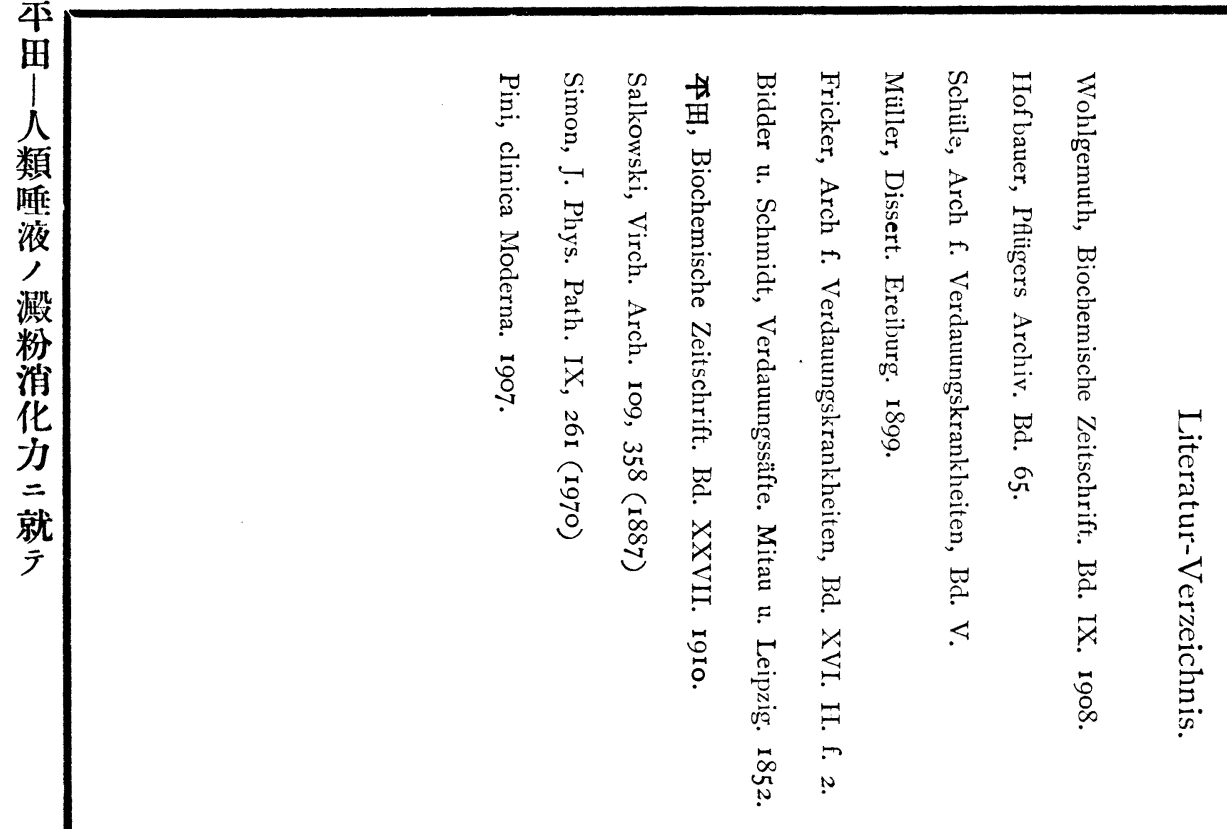

公 